\title{
Nutrient Removal Structures Using Locally-Sourced Iron and Aluminum By-Products Reduce Nutrient Runoff from Broiler Production Facilities
}

\author{
Sheri L. Herron ${ }^{1}$, Andrew N. Sharpley ${ }^{2 *}$, Kristofor R. Brye², James M. Burke² \\ ${ }^{1}$ Ecosustain, LLC, Dripping Springs, TX, USA \\ ${ }^{2}$ Department of Crop, Soil, and Environmental Sciences, University of Arkansas, Fayetteville, AR, USA \\ Email:*sharpley@uark.edu
}

How to cite this paper: Herron, S.L., Sharpley, A.N., Brye, K.R. and Burke, J.M. (2020) Nutrient Removal Structures Using Locally-Sourced Iron and Aluminum By-Products Reduce Nutrient Runoff from Broiler Production Facilities. Journal of Environmental Protection, 11, 332-343. https://doi.org/10.4236/jep.2020.114019

Received: February 26, 2020

Accepted: April 6, 2020

Published: April 9, 2020

Copyright $\odot 2020$ by author(s) and Scientific Research Publishing Inc. This work is licensed under the Creative Commons Attribution International License (CC BY 4.0).

http://creativecommons.org/licenses/by/4.0/

\begin{abstract}
A common issue with filters designed to remove nutrients from runoff is their reduced effectiveness in high-flow conditions. To overcome this challenge, it was determined that nutrient removal from broiler-house fan dust could be more effective if nutrient removal was conducted at the nutrient source. The objective of this study was to evaluate the effectiveness of containment trays (CTs) holding locally sourced by-products installed adjacent to broiler house fans at the University of Arkansas Savoy broiler production facility to capture nutrients released from dust during rainfall over four years (2013 to 2017). By-products used were locally sourced, iron-based red mud (RM) generated during the manufacture of steel belts for tires and alum-based drinking water treatment residual (WTR), where both materials have large phosphorus (P) sorption capacities. Four-year mean annual concentrations of dissolved $\mathrm{P}$ of through-flow from RM CTs were consistently below $0.7 \mathrm{mg} \cdot \mathrm{L}^{-1}$ and below $1.6 \mathrm{mg} \cdot \mathrm{L}^{-1}$ for WTR CT through-flow. This equated to an average 11- and 4-fold decrease for RM and WTR, relative to concentrations in runoff from same-sized plots adjacent to sidewall fans, demonstrating their potential to trap $\mathrm{P}$ at the source and decrease $\mathrm{P}$ runoff to nearby flowing waters. While there was no significant decline in RM or WTR effectiveness over the four-year study, further work needs to be conducted to determine the lifespan of CTs. Use of RM and WTR in CTs at poultry broiler production facilities, along with their subsequent land application, has the potential to reduce the amount of by-product materials that are currently landfilled.
\end{abstract}




\section{Keywords}

Nitrogen Runoff, Phosphorus Runoff, Poultry Production, Red Mud, Water Quality, Water Quality, Water Treatment Residual

\section{Introduction}

Accelerated cultural eutrophication continues to be a concern in the U.S. and globally [1], with agricultural production systems identified as a major contributor, for example in the Chesapeake Bay Watershed [2] [3], Mississippi River Basin [4], Florida's inland and coastal waters [5], Lake Erie Basin [6] [7] [8] and China [9]. Concerns have centered on regions with spatially concentrated livestock systems, where nutrients, particularly $\mathrm{P}$, in manure produced exceed local crop requirements, leading to an increased risk of P runoff [10]. For broiler production systems, additional concerns were focused on nutrient runoff from dust deposit adjacent to broiler house ventilation fans [11] [12].

Accentuating the potential loss of nutrients is the fact that the water solubility of dust $\mathrm{P}$ was, on average, three times greater than that in the litter [11]. Strategies to reduce nutrient runoff now target nutrient sources, rather than treating receiving waters, to most effectively decrease impairment [13] [14] [15]. Thus, removing nutrients from runoff water prior to water leaving the production area is the most cost-effective, on-farm conservation practice (CP).

To be consistently effective, P-removal systems must able to treat and transmit large volumes of runoff. As runoff volumes from land around broiler production houses can easily overload available systems, P-removal systems would not be consistently effective. In addition, installation and maintenance of P-removal systems are expensive and labor intensive, making P-removal systems unrealistic as a permanent, on-farm solution. Removing $\mathrm{P}$ at the source avoids the issue of hydraulic overload, because it would no longer be necessary to treat large volumes of runoff.

Herron et al. [16] [17] reported RM and WTR could sorb 25 and $10 \mathrm{~g} \cdot P \cdot \mathrm{kg}^{-1}$ of by-product, respectively, with hydraulic conductivities of 8.0 and $15.4 \mathrm{~cm} \cdot \mathrm{cm}^{-1}$, prior to being used to sorb $\mathrm{P}$ from broiler-house ventilation dust. Further research by Herron et al. [17] [18] determined an optimal thickness of $8 \mathrm{~cm}$ for the RM and WTR by-products to retain $\mathrm{P}$ and at the same time allow infiltration of water for efficient $\mathrm{P}$ removal ( $96 \%$ to $99 \%$ of added P by WTR and RM, respectively).

To be most cost-effective, $P$ retention media need to be locally sourced, readily available, and inexpensive. Industrial by-products with large P-retention capacities that are currently being landfilled are ideal candidates if the by-products do not contain hazardous materials. Two such byproducts are alum-based WTRs, generated where alum is used to flocculate suspended solids from municipal water supplies, and any of a group of by-products variously referred to as red muds or iron filter cakes, which consist primarily of iron oxides and oxyhy- 
droxides. The effectiveness of a CT is not only a function of the design and placement, but is also a function of the capacity of the retention media to capture and retain the target nutrients [19] [20].

This paper describes a four-year study to test the hypothesis that CTs filled with P-sorbing materials and recessed into the ground adjacent to broiler house fan outlets, could sequester P from dust and decrease P runoff potential. Dust from broiler houses settles on top of the P-sorbing materials. During a rainfall event, rainfall first encounters the dust and leaches nutrients into the underlying P-sorbing materials where they are sequestered. In the research described in this paper, the bottom of CTs was enclosed by plastic so that through-flow could be collected and analyzed. If effective, on-farm CTs would not have enclosed bases, allowing through-flow to drain into underlying soil.

\section{Material and Methods}

\subsection{Containment Tray Design}

Containment trays were constructed of polyvinyl chloride (PVC) side boards (1.9-cm thick and 22.9-cm wide) and vinyl-coated wire mesh bottoms. The CTs were then installed adjacent to four sidewall ventilation fans at the University of Arkansas Savoy broiler production facility in northwest Arkansas in April 2013. Containment trays were sized to capture the majority of dust particles where they were deposited and were 1.2-m wide by 1.8-m long (Figure 1(a)). Landscape

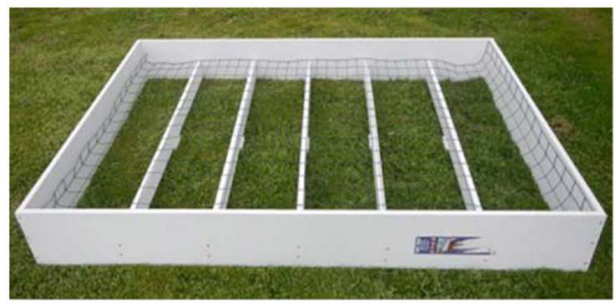

(a) Containment tray structure

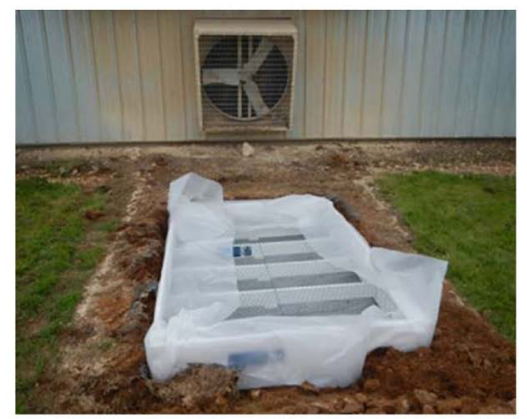

(b) Containment tray with liner

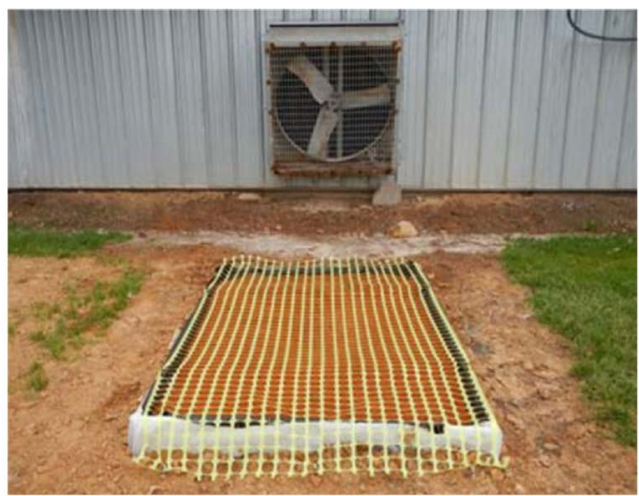

(c) Installed containment tray with red mud

Figure 1. Containment tray structure (a), design (b), and installation (c) at Savoy Broiler Production Facility. 
fabric lined the bottom and inner sides of the CT to retain the by-product and trapped dust. Soil below and along the sides of the CTs was lined with $6-\mathrm{mm}$ PVC sheeting to capture leachate for analyses (Figure 1(b)). Mesh covering the CTs helped retain dust exhausted from the ventilation fans (Figure 1(c)).

Installed trays were recessed into the ground level, so rainfall would percolate through the dust and by-product evenly (Figure $1(\mathrm{c})$ ). A $2.5-\mathrm{cm}$ interior diameter PVC pipe was installed at one corner to allow access for a pump tube to collect the leachate, which was accomplished using a long, flexible tube connected to a peristaltic pump. Duplicate CTs were filled with RM or WTR, leaving $5 \mathrm{~cm}$ of the tray exposed to eliminate runoff or run on of water. Thus, CTs adjacent to fans 1 and 3 were filled with RM and those adjacent to fans 2 and 4 filled with WTR [16].

Natural rain falling on the CTs leached the dust through the by-product, trapping particulate matter and sorbing P. A $10.2-\mathrm{cm}$ free air space below the by-product allowed capture of the leachate, which was pumped out after each rainfall event and analyzed for $\mathrm{P}$ and nitrogen $(\mathrm{N})$ (Figure 2). For broader use of the CTs, leachate would be allowed to infiltrate into the underlying soil. Annual rainfall at the study site was $117,91,137$, and $91 \mathrm{~cm}$ in 2013, 2014, 2015, and 2016, respectively, with a 30-year average of $116 \mathrm{~cm}$ (from U.S. Climate Data at https://www.usclimatedata.com/climate/fayetteville/arkansas/united-states/usar0 189).

\subsection{Containment Tray Leachate Collection and Analyses}

Following storm events that generated runoff, leachate was pumped from the cavity beneath the CTs. Leachate was subsampled and $1 \mathrm{~L}$ was retained from each tray for analysis. Leachate was filtered through a $0.45-\mu \mathrm{m}$ membrane filter
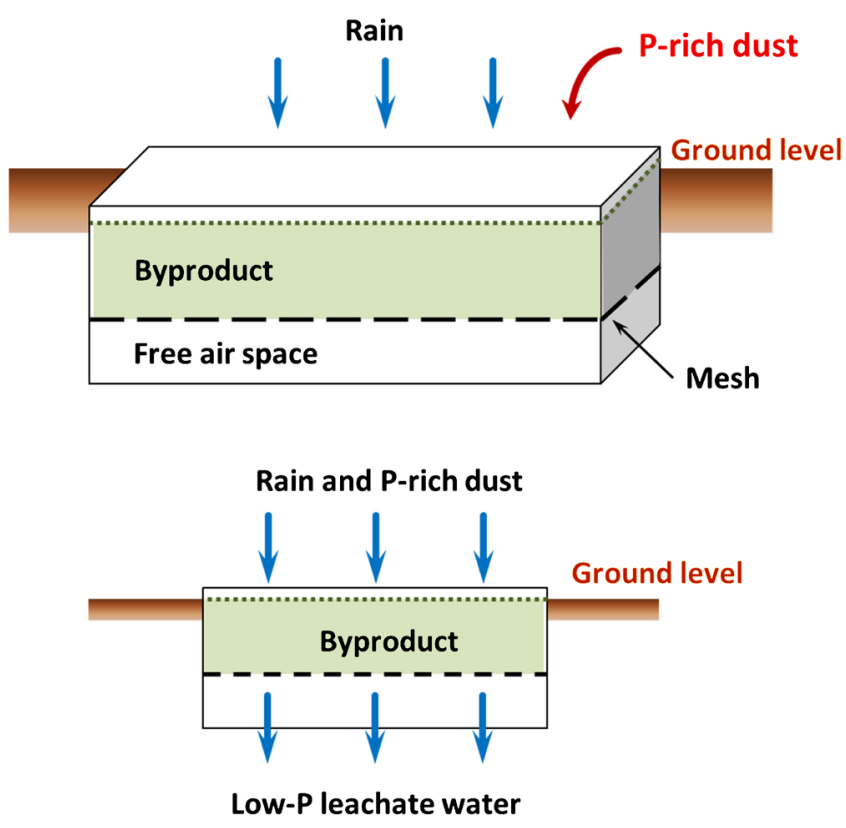

Figure 2. Schematic of containment tray design. 
immediately after collection and stored at $4^{\circ} \mathrm{C}$ until analyzed for dissolved $\mathrm{P}$ (DP) by the colorimetric molybdenum-blue method of Murphy and Riley [21]. Nitrate- $\mathrm{N}\left(\mathrm{NO}_{3}-\mathrm{N}\right)$ and ammonium- $\mathrm{N}\left(\mathrm{NH}_{4}-\mathrm{N}\right)$ were analyzed colorimetrically by flow-injection analysis (Lachat Instruments QuickChem 8500, Loveland, $\mathrm{CO})$. One hundred twenty-five milliliters were acidified with 12 drops of concentrated sulfuric acid for sample preservation, and analyzed for TP and TN using persulfate/autoclave digestion [22]. Total $\mathrm{P}$ was determined by spectrophotometry (Beckman Coulter, Pasadena, CA), and total N (TN) was determined by flow-injection analysis (Lachat Instruments QuickChem 8500, Loveland, CO). One hundred twenty-five milliliters were gravimetrically analyzed for total solids after oven drying at $105^{\circ} \mathrm{C}$ for 12 hours.

\subsection{Statistical Analyses}

Statistical differences among mean concentrations of DP, TP, $\mathrm{NH}_{4}-\mathrm{N}, \mathrm{NO}_{3}-\mathrm{N}$, and TN of CT through-flow were determined by t-tests as a function of RM and WTR by-products and as a function of year for each CT using JMP Version 14.1 [23]. All relationships are reported as statistically significant at the $p<0.05$ level.

\section{Results and Discussion}

\subsection{Nutrients in Containment Tray Through-Flow}

The concentration of DP measured in each through-flow event from the CTs is depicted in Figure 3 for RM CT1 and WRT CT2. The DP concentration of through-flow from the CTs decreased with consecutive rainfall events; however, with an extended dry period between rainfalls (i.e., > four weeks), DP concentration increased due to a buildup of sidewall fan dust on the CTs. Similar trends were observed from RM CT3 and WTR CT4 and for TP, $\mathrm{NO}_{3}-\mathrm{N}, \mathrm{NH}_{4}-\mathrm{N}$, and TN concentrations (data not shown).

The concentration of $\mathrm{P}$ in CT through-flow was consistently less for RM than WTR $(p<0.05$; Table 1). For instance, mean annual DP concentration of through-flow for RM CTs was consistently below $0.7 \mathrm{mg} \cdot \mathrm{L}^{-1}$, and varied little $(p>0.05)$ among years and between duplicate trays (Table 1). For WTR, through-flow DP concentrations were below $1.6 \mathrm{mg} \cdot \mathrm{L}^{-1}$.

There was no difference in mean annual $\mathrm{P}$ and $\mathrm{N}$ concentrations, except for TN in the RM CT, of through-flow for RM or WTR CTs among study years ( $p<$ 0.05 ; Table 1 ). This was the case even though through-flow volume varied from year to year, indicating a consistency in performance of the by-products to remove $\mathrm{P}$ irrespective of through-flow volume. Through-flow volume varied as a function of rainfall, with annual rainfalls of 117, 91, 137, and $91 \mathrm{~cm}$ in 2013, 2014,2015 , and 2016, respectively.

While there was no difference $(p>0.05)$ in through-flow P concentration of WTR CTs, mean annual concentration of DP in 2016 was greater than that in 2013 (Table 1). This indicates that the retention capacity of WTR may have been starting to decrease. 


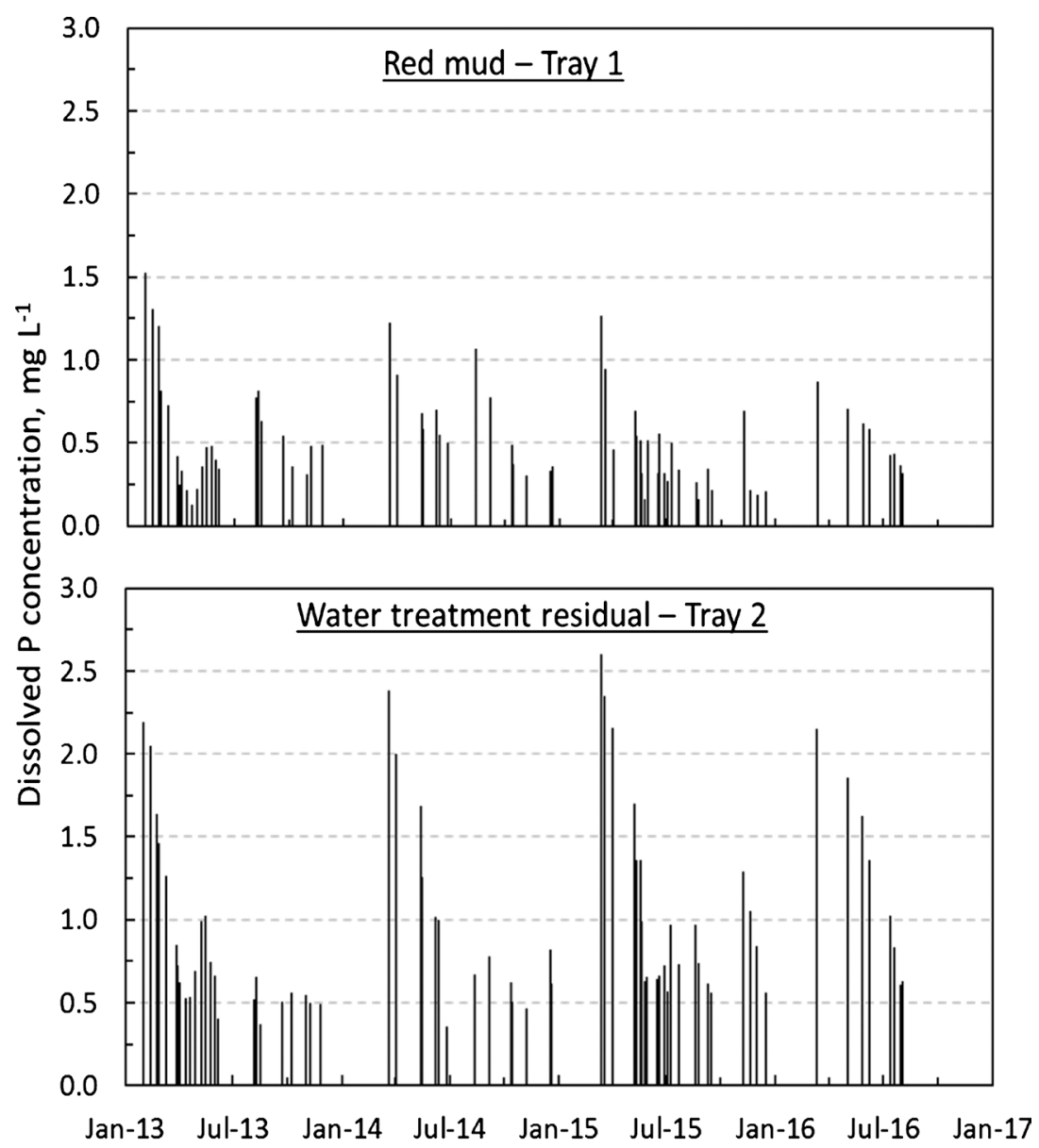

Figure 3. Dissolved P concentration in through-flow events from red mud (Tray 1) and waters treatment residual (Tray 2) containment trays, adjacent to sidewall fans 1 and 2 for 2013 to 2016 study period.

Averaged across the four years of study (2013 to 2017), through-flow P and N concentrations were similar for duplicate RM and WTR CTs (Table 1). However, the four-year average concentrations of $\mathrm{DP}, \mathrm{TP}, \mathrm{NO}_{3}-\mathrm{N}$, and $\mathrm{NH}_{4}-\mathrm{N}$, and $\mathrm{TN}$ were significantly lower in through-flow from RM than WTR CTs $(p<0.05$; Table 1).

\subsection{Efficacy of Nutrient Removal by Containment Trays}

The concentrations of $\mathrm{P}$ and $\mathrm{N}$ released from poultry house dust were estimated as the mean concentration of $\mathrm{P}$ and $\mathrm{N}$ in runoff induced from simulated rainfall plots adjacent to the four sidewall fans of the poultry houses on the Savoy Farm, as reported in Herron et al. [16]. Mean concentrations of DP, TP, $\mathrm{NO}_{3}-\mathrm{N}$, $\mathrm{NH}_{4}-\mathrm{N}$, and $\mathrm{TN}$ of runoff from sidewall plots adjacent to sidewall fans were 5.5, 8.7, 21.2, 25.2, and $51.8 \mathrm{mg} \cdot \mathrm{L}^{-1}$, respectively.

Assuming these runoff concentrations approximate the potential concentrations of $\mathrm{P}$ and $\mathrm{N}$ released to CTs from house dust during rainfall, both RM and WTR appreciably decreased DP and TP concentrations (Figure 4). For DP, this amounted to an average 11- and 4-fold decrease and a 13- and 5-fold TP decrease 
for RM and WTR, respectively. For N, RM and WTR CTs decreased the concentration of $\mathrm{NO}_{3}-\mathrm{N}, \mathrm{NH}_{4}-\mathrm{N}$, and $\mathrm{TN}$ in through-flow compared with approximated concentrations leached from house dust to a smaller extent than for P (Figure 5).

Table 1. Through-flow volumes and mean annual concentrations of $\mathrm{P}$ and $\mathrm{N}$ in red mud and water treatment residual containment trays and four-year study average.

\begin{tabular}{|c|c|c|c|c|c|c|c|}
\hline \multirow{2}{*}{ Year } & \multirow{2}{*}{$\begin{array}{c}\text { No. } \\
\text { flow events }\end{array}$} & \multirow{2}{*}{$\begin{array}{c}\text { Through-flow } \\
\text { L }\end{array}$} & Dissolved P & Total P & Nitrate-N & Ammonium-N & Total N \\
\hline & & & \multicolumn{5}{|c|}{$\mathrm{mg} \cdot \mathrm{L}^{-1}$} \\
\hline \multicolumn{8}{|c|}{ Red mud -Tray 1} \\
\hline 2013 & 24 & 2,41 & $0.565 \mathrm{a} \dagger$ & $0.735 \mathrm{a}$ & $23.54 \mathrm{a}$ & $7.03 \mathrm{a}$ & $35.26 \mathrm{a}$ \\
\hline 2014 & 14 & 2338 & $0.630 \mathrm{a}$ & $0.747 \mathrm{a}$ & $24.01 \mathrm{a}$ & $1.27 \mathrm{a}$ & $29.21 \mathrm{ab}$ \\
\hline 2015 & 24 & 3565 & $0.435 a$ & $0.534 \mathrm{a}$ & $16.03 \mathrm{~b}$ & $3.01 \mathrm{a}$ & $24.11 \mathrm{~b}$ \\
\hline 2016 & 8 & 961 & $0.537 \mathrm{a}$ & $0.688 \mathrm{a}$ & $14.97 \mathrm{~b}$ & $5.23 \mathrm{a}$ & $25.17 \mathrm{ab}$ \\
\hline \multicolumn{8}{|c|}{ Red mud -Tray 3} \\
\hline 2013 & 24 & 2347 & $0.586 a$ & $0.727 \mathrm{a}$ & $16.06 \mathrm{a}$ & $5.07 \mathrm{a}$ & $26.70 \mathrm{a}$ \\
\hline 2014 & 14 & 1595 & $0.506 \mathrm{a}$ & $0.738 \mathrm{a}$ & $25.35 \mathrm{a}$ & $1.03 \mathrm{a}$ & $29.33 a$ \\
\hline 2015 & 24 & 3624 & $0.403 a$ & $0.534 \mathrm{a}$ & $14.25 \mathrm{a}$ & $7.20 \mathrm{a}$ & $26.11 \mathrm{a}$ \\
\hline 2016 & 8 & 941 & $0.468 \mathrm{a}$ & $0.561 \mathrm{a}$ & $13.13 \mathrm{a}$ & $7.50 \mathrm{a}$ & $22.16 \mathrm{a}$ \\
\hline \multicolumn{8}{|c|}{ Water treatment residual -Tray 2} \\
\hline 2013 & 24 & 2346 & $0.852 \mathrm{a}$ & $1.001 \mathrm{a}$ & $49.00 \mathrm{a}$ & $34.66 \mathrm{a}$ & $87.25 \mathrm{a}$ \\
\hline 2014 & 14 & 1773 & $1.010 \mathrm{a}$ & $1.368 \mathrm{a}$ & $51.46 \mathrm{a}$ & $33.40 \mathrm{a}$ & $96.32 \mathrm{a}$ \\
\hline 2015 & 24 & 4275 & $1.052 \mathrm{a}$ & $1.230 \mathrm{a}$ & $43.72 \mathrm{a}$ & $15.00 \mathrm{a}$ & $65.35 \mathrm{a}$ \\
\hline 2016 & 8 & 921 & $1.259 \mathrm{a}$ & $1.398 \mathrm{a}$ & $38.32 \mathrm{a}$ & $35.59 \mathrm{a}$ & $88.98 \mathrm{a}$ \\
\hline \multicolumn{8}{|c|}{ Water treatment residual -Tray 4} \\
\hline 2013 & 24 & 2601 & $0.820 \mathrm{a}$ & $0.987 \mathrm{a}$ & $44.87 \mathrm{a}$ & $39.60 \mathrm{a}$ & $91.13 \mathrm{a}$ \\
\hline 2014 & 14 & 2119 & $1.012 \mathrm{a}$ & $1.190 \mathrm{a}$ & $71.47 \mathrm{a}$ & $17.59 \mathrm{~b}$ & $98.44 a$ \\
\hline 2015 & 24 & 4127 & $1.137 \mathrm{a}$ & $1.300 \mathrm{a}$ & $54.06 \mathrm{a}$ & $33.99 \mathrm{a}$ & $95.94 \mathrm{a}$ \\
\hline 2016 & 8 & 1120 & $1.506 \mathrm{a}$ & $1.634 \mathrm{a}$ & $49.05 \mathrm{a}$ & $40.66 \mathrm{a}$ & $104.86 \mathrm{a}$ \\
\hline \multicolumn{8}{|c|}{ Four-year total through-flow and average concentration $\ddagger$} \\
\hline Red & mud tray 1 & $9605 \mathrm{a}$ & $0.530 \mathrm{~b}$ & $0.663 \mathrm{~b}$ & $20.08 \mathrm{c}$ & $4.30 \mathrm{~b}$ & $29.07 \mathrm{c}$ \\
\hline Red & mud tray 3 & $8506 a$ & $0.494 \mathrm{~b}$ & $0.644 \mathrm{~b}$ & $16.96 \mathrm{c}$ & $5.27 \mathrm{~b}$ & $26.51 \mathrm{c}$ \\
\hline Wate & er trt. tray 2 & $9315 \mathrm{a}$ & $0.998 \mathrm{a}$ & $1.198 \mathrm{a}$ & $46.46 \mathrm{~b}$ & $27.77 \mathrm{a}$ & $81.75 \mathrm{~b}$ \\
\hline Wate & er trt. tray 4 & $9937 a$ & $1.046 \mathrm{a}$ & $1.209 \mathrm{a}$ & $53.82 \mathrm{a}$ & $33.40 \mathrm{a}$ & $95.81 \mathrm{a}$ \\
\hline
\end{tabular}

†Concentration means followed by the same letter are not significantly different at a $p<0.05$ level. Through-flow of total volume of water captured in containment tray each year. ¥Through-flow volume and average concentration for each treatment followed by the same letter are not significantly different at a $p<$ 0.05 level. 


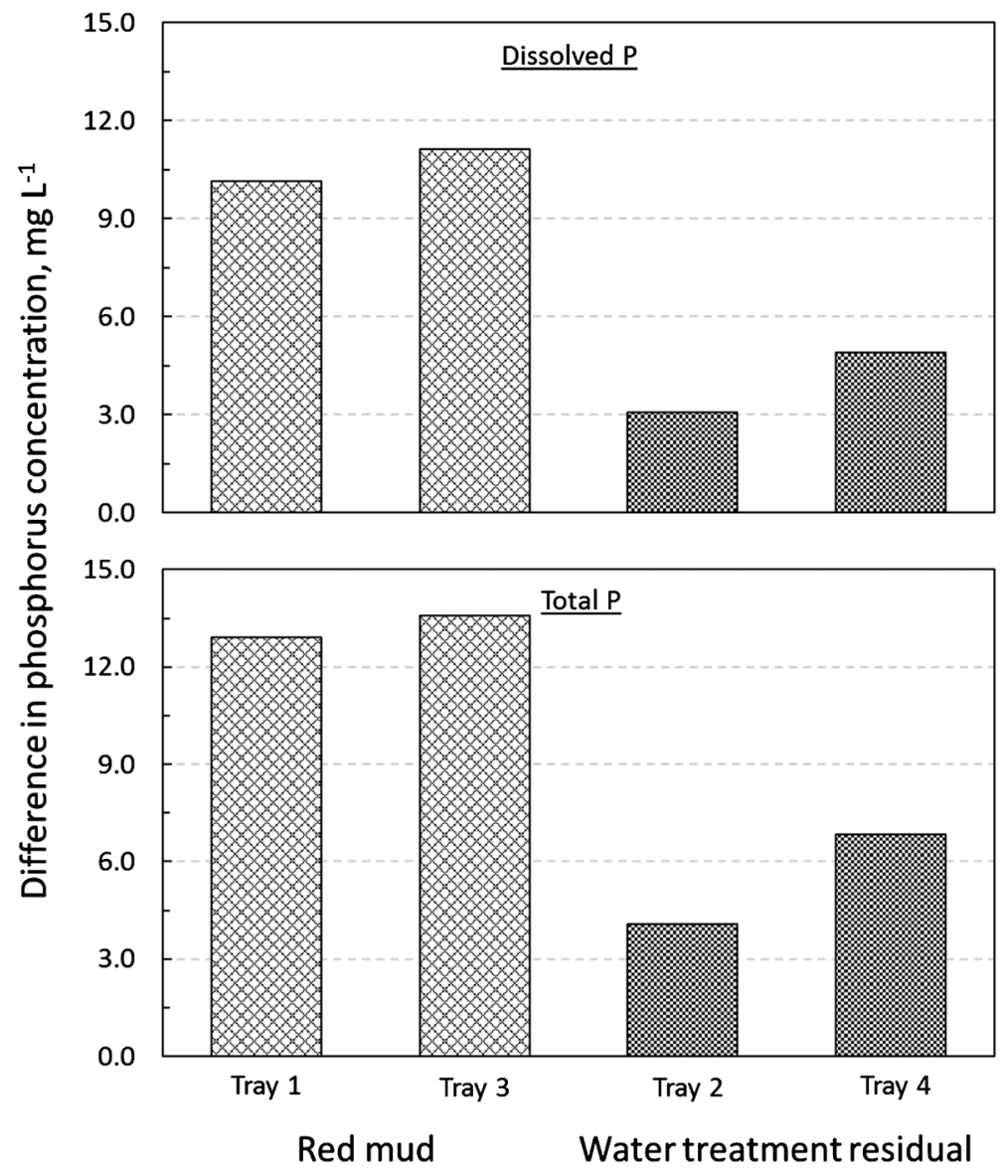

Figure 4. Difference between the 4-year mean concentrations of dissolved and total $\mathrm{P}$ in red mud and water-treatment residual containment trays and fan runoff induced by simulated rainfall. Simulated rainfall concentrations from Herron et al. [16].

\section{Conclusions}

Designed with PVC and vinyl-coated mesh, the CTs were resistant to environmental degradation from ultraviolet light, bacteria, and mold. The CTs also retained their structural integrity, despite being exposed to heavy rainfall (maximum of $9.3 \mathrm{~cm}$ in $24 \mathrm{~h}$ ) and outdoor temperatures exceeding $38^{\circ} \mathrm{C}$ and as low as $-12^{\circ} \mathrm{C}$ during the four-year study (2013 to 2017).

The trays functioned properly to trap broiler house dust and percolate rain and runoff water. Visual observations of the system during and directly following a rainfall event showed that dust accumulates on the surface and reduces infiltration of rainwater through the by-product, but does not pond and overtop the tray. The slowed infiltration rate increased contact time between through-flow and by-product in the CTs, which enhanced the effectiveness of $\mathrm{P}$ removal.

Once saturated with $\mathrm{P}$ or clogged, the by-product would be removed from the CT and land applied with broiler litter from house clean out, as evaluated and reported by Brennan et al. [24]. Evaluation of the lifespan of the 8-cm thickness of the by-products in CTs still needs to be conducted. However, this research demonstrated the potential of RM and WTR by-products placed in CTs to 


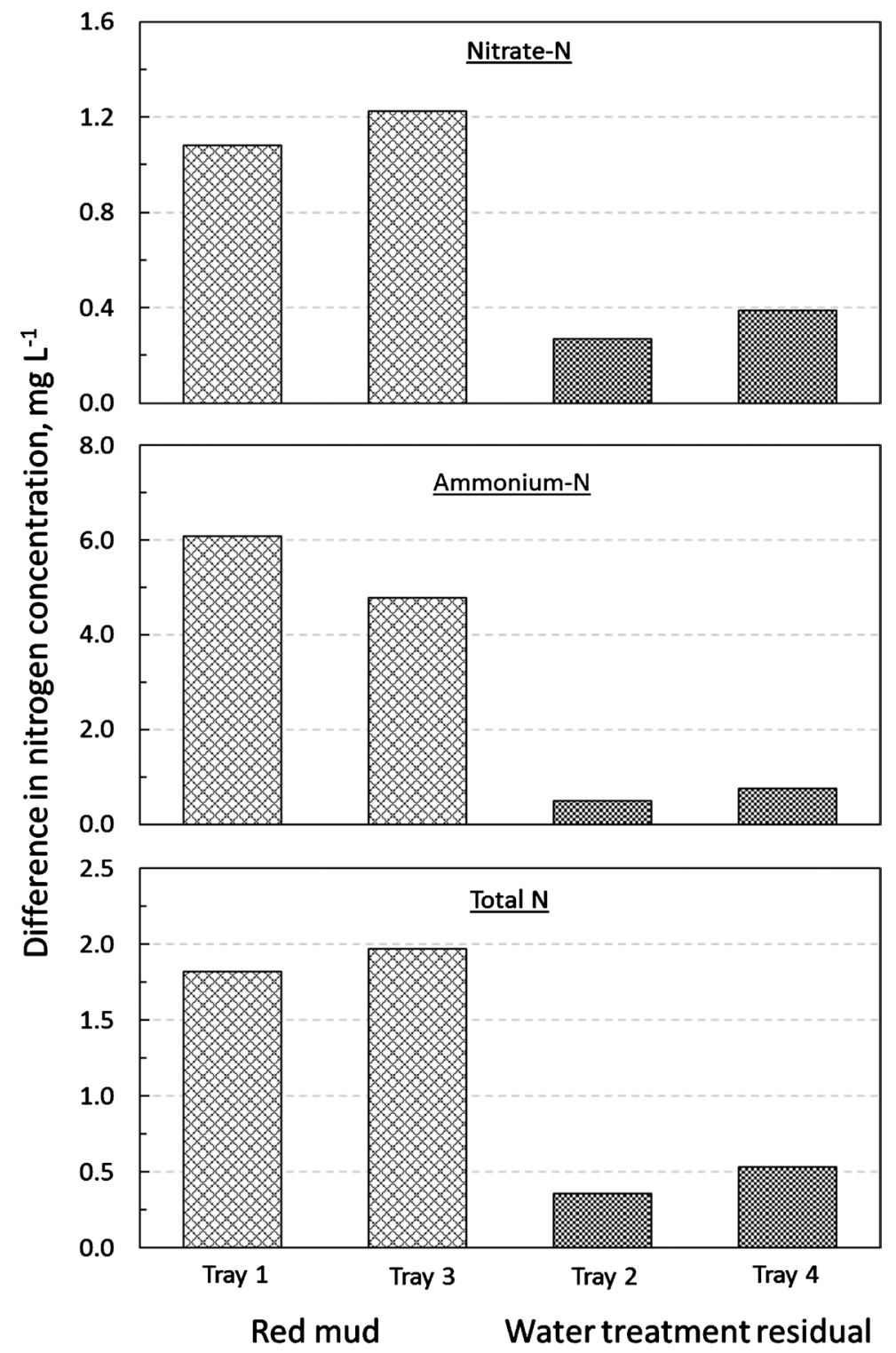

Figure 5. Difference between the 4-year mean concentration of nitrate-N, ammonium-N, and total $\mathrm{N}$ in red mud and water-treatment residual containment trays and fan runoff induced by simulated rainfall. Simulated rainfall concentrations from Herron et al. [16].

sequester $\mathrm{P}$ in house dust; thereby decreasing the quantity of $\mathrm{P}$ that could runoff and be transported to nearby flowing waters. In addition, use of RM and WTR in CTs at poultry-broiler production facilities has the potential to reduce the amount of the by-products that are currently landfilled.

\section{Conflicts of Interest}

The authors declare no conflicts of interest regarding the publication of this paper.

\section{References}

[1] Jarvie, H.P., Sharpley, A.N., Flaten, D. and Kleinman P.J.A. (2019) Phosphorus Mi- 
rabilis: Illuminating the Past and Future of Phosphorus Stewardship. Journal of Environmental Quality, 48, 1127-1132. https://doi.org/10.2134/jeq2019.07.0266 https://dl.sciencesocieties.org/publications/jeq/abstracts/48/5/1127

[2] Kleinman, P.J.A., Fanelli, R.M., Hirsch, R.M., Buda, A.R., Easton, Z.M., Wainger, L.A., Brosch, C., Lowenfish, M., Collick, A.S., Shirmohammadi, A., Boomer, K., Hubbart, J.A., Bryant, R.B. and Shenk, G.W. (2019) Phosphorus and the Chesapeake Bay: Lingering Issues and Emerging Concerns for Agriculture. Journal of Environmental Quality, 48, 1191-1203. https://doi.org/10.2134/jeq2019.03.0112 https://dl.sciencesocieties.org/publications/jeq/articles/48/5/1191

[3] U.S. Environmental Protection Agency (2010) Guidance for Federal Land Management in the Chesapeake Bay Watershed. Chapter 2: Agriculture. EPA841-R-10-002. Office of Wetlands, Oceans, and Watersheds, U.S. Environmental Protection Agency, Washington DC, $247 \mathrm{p}$.

http://www.epa.gov/owow_keep/NPS/chesbay502/pdf/chesbay_chap02.pdf

[4] Dale, V.H., Kling, C.L., Meyer, J.L., Sanders, J., Stallworth, H., Armitage, T., Wangsness, D., Bianchi, T.S., Blumberg, A., Boynton, W., Conley, D.J., Crumpton, W., David, M.B., Gilber, D., Howarth, R.W., Lowrance, R., Mankin, K.R., Opaluch, J., Paerl, H.W., Reckhow, K., Sharpley, A.N., Simpson, T.W., Snyder, C. and Wright, D. (2010) Hypoxia in the Northern Gulf of Mexico. Springer Series on Environmental Management. Springer Science, New York. https://link.springer.com/book/10.1007/978-0-387-89686-1

[5] U.S. Environmental Protection Agency (2011) Administrative Order (CWA-03-2012-0023DN). Findings of Violation and Order of Compliance, in the Matter of Mrs. Lois Alt.

https://www.farmanddairy.com/wp-content/uploads/2012/12/WV_LoisAltCWA.20 11.pdf

[6] Smith, D.R., King, K.W. and Williams, M.R. (2015) What Is Causing the Harmful Algal Blooms in Lake Erie. Journal of Soil and Water Conservation, 70, 27A-29A. http://www.jswconline.org/content/70/2/27A.extract https://doi.org/10.2489/jswc.70.2.27A

[7] Smith, D.R., Wilson, R.S., King, K.W., Zwonitzer, M., McGrath, J.M., Harmel, R.D., Haney, R.L. and Johnson, L.T. (2018) Lake Erie, Phosphorus and Microcystin: Is It Really the Farmer's Fault? Journal of Soil and Water Conservation, 73, 48-57. http://www.jswconline.org/content/73/1/48.abstract https://doi.org/10.2489/jswc.73.1.48

[8] Jarvie, H.P., Johnson, L.T., Sharpley, A.N., Smith, D.R., Baker, D.B., Bruulsema, T. and Confesor, R. (2017) Increased Soluble Phosphorus Loads to Lake Erie: Unintended Consequences of Conservation Practices? Journal of Environmental Quality, 46, 123-132. https://doi.org/10.2134/jeq2016.07.0248 https://acsess.onlinelibrary.wiley.com/doi/epdf/10.2134/jeq2016.07.0248

[9] Zhang, W., Tang, X., Feng, X., Wang, E., Li, H., Shen, J. and Zhang, F. (2019) Management Strategies to Optimize Soil Phosphorus Utilization and Alleviate Environmental Risk in China. Journal of Environmental Quality, 48, 1167-1175. https://dl.sciencesocieties.org/publications/jeq/abstracts/48/5/1167 https://doi.org/10.2134/jeq2019.02.0054

[10] Sharpley, A.N., Kleinman, P.J.A., Baffaut, C., Beegle, D., Bolster, C., Collick, A., Easton, Z., Lory, J., Nelson, N., Osmond, D., Radcliffe, D., Veith, T. and Weld, J. (2017) Evaluation of Phosphorus Site Assessment Tools: Lessons from the USA. Journal of Environmental Quality, 46, 1250-1256.

https://dl.sciencesocieties.org/publications/jeq/articles/46/6/1250 
https://doi.org/10.2134/jeq2016.11.0427

[11] Herron, S.L., Brye, K.R., Sharpley, A.N., Miller, D.M. and Daniels, M.B. (2015) Nutrient Composition of Dust Emitted from Poultry Broiler Houses in Northwest Arkansas. Journal of Environmental Protection, 6, 1257-1267. http://www.scirp.org/journal/PaperInformation.aspx?PaperID=61058 https://doi.org/10.4236/jep.2015.611110

[12] U.S. Environmental Protection Agency, Scientific Advisory Board (2011) Review of EPA's Draft Approaches for Deriving Numeric Nutrient Criteria for Florida's Estuaries, Coastal Waters, and Southern Inland Flowing Waters. EPA Scientific Advisory Board, Washington DC, $67 \mathrm{p}$.

http://yosemite.epa.gov/sab/sabproduct.nsf/DCC3488B67473BDA852578D20058F3 C9/\$File/EPA-SAB-11-010-unsigned.pdf

[13] Sharpley, A.N., Kleinman, P.J.A., Flaten, D.N. and Buda, A.R. (2011) Critical Source Area Management of Agricultural Phosphorus: Experiences, Challenges, and Opportunities. Water Science and Technology, 64, 945-952.

https:/iwaponline.com/wst/article-abstract/64/4/945/16951/Critical-source-area-m anagement-of-agricultural?redirectedFrom $=$ PDF https://doi.org/10.2166/wst.2011.712

[14] Stout, W.J., Sharpley, A.N., Gburek, W.J. and Pionke, H.B. (1999) Reducing Phosphorus Export from Croplands with FBC Flyash and FGD Gypsum. Fuel, 78, 175-178. https://doi.org/10.1016/S0016-2361(98)00141-0 http://www.soilsolutions.net/wp-content/uploads/2015/02/Reducing-Phosphorus-E xport-from-Croplands-using-Gypsum.pdf

[15] U.S. Department of Agriculture and U.S. Environmental Protection Agency (1999) Unified National Strategy for Animal Feeding Operations. U.S. Government Printing Office, Washington DC. https://www3.epa.gov/npdes/pubs/finafost.pdf

[16] Herron, S.L., Sharpley, A.N., Brye, K.R., Miller, D.M., Watkins, S., McCreery, D. and Daniels, M.B. (2016) Determination of Nutrient Concentrations in Simulated Rainfall-Runoff from Poultry House Dust Deposited Adjacent to Exhaust Fans. Journal of Environmental Protection, 7, 27-40.

https://doi.org/10.4236/jep.2016.71003

http://www.scirp.org/Journal/PaperInformation.aspx?PaperID=62587

[17] Herron, S.L., Sharpley, A.N., Brye, K.R. and Miller, D.M. (2016) Optimizing Hydraulic and Chemical Properties of Iron and Aluminum Byproducts for Use in On-Farm Containment Structures for Phosphorus Removal. Journal of Environmental Protection, 7, 1835-1849. https://doi.org/10.4236/jep.2016.712146 http://file.scirp.org/pdf/JEP_2016112322303649.pdf

[18] Herron, S.L., Sharpley, A.N., Brye, K.R. and Miller, D.M. (2017) Locally Sourced Iron and Aluminum Byproducts Decrease Phosphorus Leached from Broiler House Dust Deposited near Ventilation Fans. Journal of Environmental Protection, 8, 1026-1036. https://doi.org/10.4236/jep.2017.89065

[19] Oliver, I.W., Grant, C.D. and Murray, R.S. (2011) Assessing Effects of Aerobic and Anaerobic Conditions on Phosphorus Sorption and Retention Capacity of Water Treatment Residuals. Journal of Environmental Management, 92, 960-966. https://www.sciencedirect.com/science/article/pii/S0301479710004196 https://doi.org/10.1016/j.jenvman.2010.11.016

[20] Vohla, C., Koiv, M., Bavor, H.J., Chazarenc, F. and Mander, U. (2011) Filter Materials for Phosphorus Removal from Wastewater in Treatment Wetlands: A Review. Journal of Ecological Engineering, 37, 70-89. https://doi.org/10.1016/j.ecoleng.2009.08.003 
https://www.sciencedirect.com/science/article/abs/pii/S0925857409002419

[21] Murphy, J. and Riley, J.P. (1962) A Modified Single Solution Method for Determination of Phosphate in Natural Waters. Analytical Chimica Acta, 27, 31-36. https://www.mendeley.com/catalogue/35583c9d-4ac9-3906-8050-68269ccb8850 https://doi.org/10.1016/S0003-2670(00)88444-5

[22] Patton, C.J. and Kryskalla, J.R. (2003) Methods of Analysis by the U.S. Geological Survey National Water Quality Laboratory: Evaluation of Alkaline Persulfate Digestion as an Alternative to Kjeldahl Digestion for the Determination of Total and Dissolved Nitrogen and Phosphorus in Water. U.S. Geological Survey, Water Resources Investigations Report 03-4174. U.S. Geological Survey, Branch of Information Services, Federal Center, Denver, 33 p.

https://pubs.er.usgs.gov/publication/wri034174

[23] Lehman, A., O’Rourke, N., Hatcher, L. and Stepanski, E.J. (2013) JMP for Basic Univariate and Multivariate Statistics: Methods for Researchers and Social Scientists. Second Edition, SAS Institute Inc., Mary. https://pdfs.semanticscholar.org/aef2/cf228cb19fc9c4e69803c3318141ba929337.pdf

[24] Brennan, R.B., Murnane, J.G., Sharpley, A.N., Herron, S., Brye, K.R. and Simmons, T. (2019) Soil Phosphorus Dynamics Following Land Application of Unsaturated and Partially Saturated Red Mud and Water Treatment Residuals. Journal of Environmental Management, 248, Article ID: 109296.

https://doi.org/10.1016/j.jenvman.2019.109296 